\title{
MOTIVATIONAL STRUCTURE AND ORIGIN OF BUSINESS NAMES
}

\author{
Iryna Oliinyk \\ Taras Shevchenko National University of Kyiv, Kyiv, Ukraine \\ irenoliinik@gmail.com \\ Larysa Ruban \\ Taras Shevchenko National University of Kyiv, Kyiv, Ukraine \\ mlarissa@ukr.net \\ Liudmyla Shevchenko \\ Taras Shevchenko National University of Kyiv, Kyiv, Ukraine \\ shevmila@gmail.com
}

\begin{abstract}
The paper deals with motivational structure of business names that determines the choice of strategy for naming. The article considers the origin of business names and concentrates on the fact that business names' formation requires the right combination of objective information and subjectivity. Business names of restaurants in Brussels are studied. The article analyses the requirements that business names should meet, presents the main components of their motivational structure and proposes a new classification of business names, taking into consideration their motivational and structural characteristics A new classification of business names presented in the paper includes 8 different categories. The paper defines a correlation between the motivational structure of business names and the degree of persuasion they possess. The article demonstrates the use of different kinds of business names and their relevance for the naming process. It is shown that anthroponymic, transpositional and idiomatic business names possess the highest degree of persuasion. Toponymic, background and international business names can sometimes have a controversial effect on addressees, be irrelevant and highly questionable as potential actuators. The article concentrates on the necessity to adjust the code business names have to the needs of the target audience and shows the absence of direct correlation between transparency or vagueness of motivational characteristics and low or high level of persuasion. The paper develops recommendations for the choice of effective linguistic means of expression in business names creation and proposes topics for further research in the field.
\end{abstract}

Keywords: motivation; business names; persuasion; communication; perception.

\section{Introduction}

Modern society represents a multicultural phenomenon with new complicated and diversified forms of communication (Hauser and Fitch 2003, Riley, 2007). Not only do we speak about direct communication, that means simultaneous existence of two or more interlocutors giving immediate answers, but also about the one, where we have a real addresser and imaginary addressees. It can be true for graffitis on the walls, street nameplates and also business or commercial names. The latter constitute some particular kind of communication, as giving a name to a business tackles a lot of matters at once: firstly in such a way owners provide prospective customers with information about products or services available, secondly, they try to attract customers and persuade them to use these products or services, and at last, a business sign is a great opportunity for the owners to express themselves, showing some features of their personality.

The problem is how to combine all of this successfully and create such a name that will contribute to the commercial success of a company. Is it enough to inform only about the profile of activity of a business, or it is necessary to add subjectivity, personal experience, some common indices to make a business name (BN) work?

$\mathrm{BN}$ is a text, which is directed at addressees and takes into consideration their level, heterogeneous one, that is why such texts require the use of common words, easily understandable in everyday life, and simplified syntactic structures. It is generally considered that every oral or written utterance has a stable sense, placed into it by the speaker. This sense will be decoded by the receiver of the message if he or she possesses the same code or speaks the same language. The texts of BN are meant to influence addressees, to spark interest in the product or service. So, BN should have not only informational function but also express something different from the direct sense of the words, make secondary senses play, let connotations show their relevance. BN can be considered as a concise text, where the intention of the addresser is clearly stated: Gourmets Every-Day for a restaurant should mean the guests eat there dainty dishes all the time.

As we see, speaking about BN we should take into account the fact that a lot of cross-sectoral issues should be considered here, i.e. this subject is connected with both linguistics and marketing. That is why the majority of authors dealing with BN analyse linguistic facts with an eye on product promotion. Sériot (2013) approaches BN from a communicative perspective. He argues that in the contemporary environment one 
important function of a brand name is to generate a tie between the product and the consumer and shows how this relationship can be linguistically established (Sériot, 2013). Argenti and Forman (2002) consider the psychological effect of $\mathrm{BN}$ on addressees and make the accent on identity reflecting BN that they regard as having a significant impact on perceptions and attitudes of customers. Riley (2007) highlights the fact that $\mathrm{BN}$ act as cultural mediators: they deal with the transfer of information in a multicultural environment and promote the idea of common cultural space. Bergien (2005) looks at the criteria according to which company names are formed and tries to measure their consumer effect and purchase intentions of the customers. The subject of the study by Sjoblom (2007) concerns Finnish company names and their sound shapes. He compares new brand names with a large corpus of historical brand names and states that there are certain tendencies in the diachronic development of the names. Sjoblom (2007) also tries to distinguish strategically desirable brand name characteristics.

Thus, modern BN should meet a lot of requirements: it should attract attention of prospective customers, be catchy, trigger positive associations and be understandable to various strata of society. According to the law of efficient communication, perception of a business sign covers a few stages: at first associative and imaginative memory of the addressee is activated by motivational links, that act as a catalyst for the mechanism of perception, then emotional reaction develops, followed by emotional and evaluative attitude, and finally it leads to an effect (in our case it is to approach a company or not). In view of this, designing a $\mathrm{BN}$ requires making the right choice of strategy and tactics of naming and under the tight competition defines to an extent the future of a business (Argenti and Forman, 2002; Bergien, 2005; Sjoblom, 2007). Thus, our objective is to exploit the potential of motivational structure of $\mathrm{BN}$ and get an overview of linguistic means of expression that reside in $\mathrm{BN}$ of restaurants of Brussels. Our research is also aimed at developing recommendations for the choice of linguistic means that have the relevant degree of persuasion and are able to contribute to the success of food outlets.

\section{Methods}

The article analyses the names of restaurants in Brussels available from electronic source http://tripadvisor.fr in January 2018. Their general number is 1154 and they are chosen by continuous sampling method. We believe that to identify the lexical meaning of proper nouns it is necessary not only to study links of the unit within the lexical system but also take into consideration its phonetic and morphological features.

We also use component analysis method, that allows us to deeper penetrate into the plane of the content of $\mathrm{BN}$ and decompose their meanings into the minimum constituents. To make general conclusions about the most relevant means of $\mathrm{BN}$ formation, which possess the greatest force of persuasion, we rely on the method of inductive analysis.

\section{Results}

\section{Prerequisites for classification}

At first, we would like to develop our own classification of $\mathrm{BN}$ that will take into consideration their motivational and structural characteristics. The problem of semantic analysis of BN is of great interest for the researchers, as their significance doesn't depend only on the number of direct meanings of separate words, which constitute a commercial sign, but, in the majority of cases, includes subjective assessment, connotations, and requires a thorough analysis of extralinguistic data. It should be noted that lately, BN attracts more and more attention of linguists, as these lexical units should be considered from different points of view, and pragmatic aspect takes here the most important place. Consequently, to make a BN function efficiently, i.e. have a pragmatic influence on the addressee and rouse him to action (in our case to use a product or a service), there should be identity of intention of the naming subject and prospective addressee perception (Pinker and Bloom, 1990; Tomasello, 2003).

In our paper, we consider the motivational structure of business names of the restaurants, as we believe they are one of the most flexible and adaptable to the changes that globalisation requires on the one hand, and lean toward classical values on the other one (Sériot, 2013). Besides, there doesn't exist any legal frame, as in the case of some other institutions (for example notarial offices). Initially, we will choose three main components in the motivational structure of BN: identifying, qualifying and differentiating ones. The first one makes an emphasis on company profile - in our case these are such business names as Brasserie de la ville, Bar des amis, Restaurant le Tournant, Taverne Manneken Pis, Café de l'Avenue (here we mean the first elements in all these five business names, other elements will be analysed later). The second one specifies the products or services, offered by the business: Poivre \& Sel, Déjeuner sur l'herbe, Quiche \& 
Gaufre, La Truffle noire, Eclairs et Gourmandises, Verre Y Table. Both components relate to each other as generic and specific notions. As for differentiating component, this is the one that expresses intentions of the naming subject and its ideas of persuading the addressee in the best way. Its function is to distinguish $\mathrm{BN}$ in a raft of the similar ones and is the most interesting from the point of view of motivating indices. That said, it can be seen even from the business names mentioned above that the first and the second components can be rarely presented separately, later we will see that the large majority of cases show the combination of two or three of components.

\section{Eight categories of business names}

Our next step is to penetrate deeper into the semantic structure of BN under consideration. To reach this goal we will divide BN into anthroponymic, toponymic, background, transpositional, idiomatic, play on words, sentence based, international.

In the case of anthroponymic BN, we mean use of names and family names of the owners or other people, as a whole they constitute 9\% (104 BN) of all the BN: Le Léonard, Luka, Léopold, Laurent Gerbaud, Jef, Pièrre Ledent, Meert, Thérèse et Dominique, Bruneau, Henri, François, Le Max, Arcadi, Lola, Alexandre, Cécila, La Marie Joseph, Galya, Michael Collins, Gaston, Jules et Charles, Kolya. Another part of anthroponymic $\mathrm{BN}$ is represented either by the combination of name with preposition chez, which has some additional connotation of being at somebody's place and feeling at home: Chez Soje, Chez Nico, Chez Fernand, Chez Patrick, Chez Léon, Chez Oki, Chez Anési, Chez Hassan, Chez Fatma, Chez Max, Chez Richard, Chez Saly, Chez Mauricette, Chez Mimoun, Chez Théo le Grec, or by the combination of name with words that reflect family or other close relationships between people: Les Frères Romano, Le Père Yvan, Le Fils d' Antoine, L'ami Roger, Mamy Louise, Le Garçon de Toto. Approximately one fifth of BN from this category are represented by the combination identifying element + proper name: Café Georgette, Maison Antoine, Maison Dandoy, Darcis Chocolatier, Resto Martin, Herman's Bistro, The Restaurant by Pierre Balthasar, Todt's Café, Le Restaurant de Rob, Brasserie Ploegmans, Pipaillon La Conserverie, Brasserie Jules, Rino Son Resto, Bistro Emile, Café Claude, Scott's Café Bar, Brasserie Georges, Victor Bar\&Restaurant, Friture René.

As for toponymic BN, they are not very numerous $-3 \%(35 \mathrm{BN})$, and remind places in different corners of the Earth: Le Nil, Dèlphes, San Remo, Le Caire, Rhodes, A Brussel, Athènes, Le Milan, Copacabana Sablon, The Deli, Malte, Antarctique, Toscana, Le Corrège, Saint-Boniface (that is in Saint-Boniface street), Santorini, Seoul, Mykonos, Canterbury, Shanghai, La Vieille Bosnie. The majority of them include identifying elements - Restaurant Brighton, Emirates Lounge Bar, Chicago Café, café Portugal, and reflect the location of the restaurant: Friterie Tabora, Friterie Saint-Josse, Frit Flagey, Bozar Brasserie, Boston Steakhouse Rogier, Café du Sablon, Brasserie Léopold (situated in Léopold area of Brussels), Brasserie Mérode, Champagnothèque de Bruxelles, Restaurant de l'Atomium, Restaurant de la Bourse, Restaurant Saint Catherine, Café Le Lombard, Brussels Grill Grand Place.

The next category we will consider is background $\mathrm{BN}(4 \%$ or $46 \mathrm{BN})$ that evoke associations about background information from the addressee. Background information is a knowledge that the majority of people possess owing to general erudition, consequently, the use of such BN contributes to actualisation of some relevant connotations in the brain of the recipient and serves as a powerful tool of motivation.

BN Chez Montaigne brings back symbolic figure of the philosopher of French Renaissance Michel de Montaigne, his portrait and the quotation "Mon métier, et mon art, c'est vivre" by Montaigne can be found on the site of the restaurant. La Bastoche is a slang name for Bastille prison in Paris; Le Mazarin, Visconti, Nerone, Le Médicis, Amadeus, le Louis XV, El Gréco, Confucius, Le Mucha, Le Raphael, Lord Byron, Magic Rubens evoke famous and influential personalities that lived in different parts of the globe down the ages. Others, such as Poseidon, Arion, l'Atlantide, Héracles, Pantalone, l'Arlequin, Saint Georges, San Giacomo, San Donato, L'autre Orfeo, Olympia, l'Eden, Notos recall some characters of myths of Ancient Greece, the Bible, Italian commedia dell'arte. BN Le Gambrinus is a hint about European culture hero, the symbol of brewing. One more BN Zinneke reflects the particular spirit of Brussels, as in its dialect means "somebody from Brussels". La Fin de Siècle is an idiom that means closing one era and onset of another one. La Mamounia reveals beauties of one of Moroccan palaces, bearing the same name, la Riviera brings back French and Italian coastlines, extremely popular with tourists, Le Bugatti, is on the one hand, a reminder of the fact, that the restaurant is situated in the building of a former garage, on the other hand, it is a testimony of quality of the house. Sometimes such BN also comes with identifying lexical items: Le Brueghel Taverne, Brasserie Horta, Nasreddin Pizzeria.

A very important category is represented by transpositional $\mathrm{BN}$ that involve such semantic transpositions, as metaphor and metonymy $(49 \%$ or $565 \mathrm{BN})$. As a matter of fact, figures of speech are a 
favourite naming instrument, as concerns the names of restaurants, because they foreground multiple semes, that in every case reflect on the one hand the personality of the addresser and on the other one his pragmatic intentions (Sweetser 2017). To be sure, the semantic field of "Food and drinks" (11\% or $127 \mathrm{BN})$ is foregrounded at the first place, it can be illustrated by the examples of synecdoque, where a part instead of the whole is described: Les Trappistes, Grimbergen café, Rouge Piment, La Cotelette, Le Basilic, Les Crustacés, Le Patty Pates, Eclairs et Gourmandises, Restaurant Chou, Gaufre de Bruxelles, Poivre \& Sel, Canapé Sandwicherie et Patisserie, A la Becasse, Café Steurs, la Sardine du Marseillais, Les Petits Oignons, Tranches de Cake, Citron Vert, Le Crabe Fantome, Le Croc en ville, Kaffabar, Restobières, Restaurant Le Coriandre Gourmand, La Truffe Noire, La Joue de Vache. A lot of poetical metaphors implying the idea of good food and drinks worthy compete with them: L'Atelier des Degrés, Un Gout de Chez Nous, La Boussole Brassière, Quai des Bananes, La Bôite à Pâtes, La Bôite à Tartines, La Cuve à Biere, Atelier des Pâtes, Le Comptoir des saveurs, L'eau à la bouche, De la vigne à l'assiette, L'esprit de sel, Le second degré, La mangeoire Maison Gourmande, La Trinquette, La Buvette, Quartier Gourmand, Garage à manger, La Charrette Gourmande, Casse-Croute.

When it comes to other transpositional BN, it should be noted that they refer to different semantic fields. An important part (14\% or $161 \mathrm{BN})$ of transpositional BN foreground the semantic field "People", and more specifically the micro field "Family relationships" that can be considered as a tool of intimacy, an attempt to reduce the communicative distance between communicators. In this case the elements of BN sound as names of acquaintances and relatives: Les Fils à Maman, Les Deux Frères, Les Fils de Jules, La Soeur du Patron, Chez Marraine, Les Enfants du Pirée, Aux Enfants Terribles (a hint at the novel by Jean Cocteau), Tontons, l'Oncle de Margaux, Les Frères Sen, Tonton Chami. Sometimes the structure of BN includes evaluative elements that aim to attract addressee's attention by adding some peculiar connotations and correspond to colloquial usage: Ma Folle de Soeur, Mon Fou d'Mari. The same shade of meaning is expressed by BN L'Idiot du Village, Les Potes (colloquial) en Toques, Pei-Mei (girls and boys in Brussels dialect), Madame Chapeau, Les Super Filles du Tram. BN Ami, Bar des Amis, Comme chez Soi, Les Uns avec les Hotes are also directed at highlighting closeness between communicators. Metonymies involving the names of agents making meals and drinks or consuming goods: Gourmets Every-Day, Au Brasseur, L'Ecailler du Palais Royal, La Belle Maraichère, La Femme du Sommelier. Other BN, belonging to this semantic field, present different characteristics of people - age, profession, personal features, but in every case they attract attention of addressees by their personal touch: Le Vieux, Le Bourgeois, Archiduc, Chatelain, L'héritier, Le petit Boxeur, Brasserie le Pirate, Colonel, Le Traminot, le Forestier, La Brocante, L'Affranchi, Le Milord, Chenapan, Les Canailles du Chatelain (two last BN include colloquial elements, that attract addressees by their odd and unconventional character). Eventually, BN involving localising elements can be identified among such BN: Le p'tit Belge, Le clan des Belges, Au Suisse, Le Roi des Belges, Au petit Suisse.

A number of BN refer to the "Phenomena and objects of nature" (5\% or $57 \mathrm{BN})$ : L'Océan, Le Pré Salé, La Rose Blanche, Le Crachin, Le Grain, Aux Portes de la Mer, L'Arc en Ciel, Psylophone (a kind of magic mushrooms), Le Camélia, Le Nénuphar, Haricot Magique, La Branche d'Olivier, Les Foudres, Coquelicot, Le Vent du Sud, N'Go Soleil, L'Ilot Corse. Even more numerous are BN that refer to the microfield "Animals", those ones are accompanied by different shades of meaning: Le Lion Belge, L'Hirondelle d'Or, Le Mouton d'Or (reflect not only colour characteristics of the object, but have evaluative connotation) Le Paon Royal (also has a positive connotation), Le Dauphin, Le Chat noir, La Grenouille Bleue, L'Ane vert, Bleu Elephant, Le Pigeon Noir, Le Renard Bleu, Le Loup Voyant (uncommon combination, with human feature attached to an animal), Au Pou qui Tousse (represents a two-member sentence), Toucan sur Mer, Le Corbeau, La Cigale.

Another group of transpositional BN refer to "Infrastructure and interior objects" ( $8 \%$ or $92 \mathrm{BN})$ : Le Moulin, Taverne Restaurant La Piscine, L’Imprimerie, la Bergerie, Le Quai, la Porte Noire, le Passage à Niveaux, A la Maison, Le Lit, Le Casino, La Porte des Indes, Le Moulin de Lindekemale (both BN are accompanied by localising elements), La Grande Ferme, Les Deux Maisons, La Quincaillerie, La Villette, La Manufacture, Le Petit Pont, Le Relais Saint-Job (including localising element), Le Petit Palais, Quartier Libre, L'Horloge du Sud, Claire Fontaine, la Petite Fontaine, La Basse Cour Bruxelles, Le Grenier d'Elvire (includes an anthroponym), Le Chalet de la Foret, La Rotonde, Le Parvis, La Fabrique en Ville, Café la Pompe, La Grande Ecluse, Aux Tréteaux, La Tour d'Argent, Pavillon d'Or (these two BN evoke positive connotation owing to presence of lexical units representing precious metals), Le Cercueil (the latter is close to disruptors considered below). Synecdoques, where kitchen machines, utensils and furniture are mentioned, are also frequently used in BN: Le Fourneau de Bruxelles, La cuve à biere, Les marmites du monde, Brasserie The Spoon, Verre Y Table, Les petits bouchons, Fourchette à bicyclette, Au bon bol, Le vieux 
pannenhuis, Le Marmiton, Bonne Fourchette, Les Brassins, La Table de Mus (involves anthroponymic element Mus - Mustafa).

A considerable part of transpositional BN reflect the semantic field "Abstract notions" (7\% or $81 \mathrm{BN})$. In this case two main trends should be distinguished - in the first one the question is to mention some negative ideas, notions, tendencies and attract the addressee by means of overcoming the pattern that states the necessity of operating only positive ideas to attract prospective customers. Disruptors in this context are the following BN: Le coin du Diable, Apocalypse, A la mort subite, Au diable Vauvert, Contretemps, Le Diabolo, Les Deux Petits Diables, La Clef du Cimetière, Le Délire Parisien, L'Improbable. In the second one positive connotations are used to bring in mind ideas that are well regarded by people: L'Harmony, Taverne Espérance, Passion du Sablon, Un Monde Meilleur, Lune de Miel, Les Ailes des Anges, L'amour Fou, La Crèche des Artistes, Jour de Fête, Le Beaulieu, Au Plaisir, La Bohème, L'intemporelle, Rêve d'Asie, Au Bon Coeur, Au Bon Vieux Temps, La Paix, L'équilibre, Au Plaisir, Le Divin Caprice, Aux Mille et une Nuit, L'Intemporel. A number of BN that belong to this semantic field can be designated, as microfield “Arts": Intermezzo, Il Capriccio, Le Sibemol, Drug Opera (music notions), Le Troisième Acte, L'Entracte, Le Scénario (theatrical terms), Les caprices d'Harmony, La Bohème, Vert de Gris, aux Deux Couleurs, Vert de rouge. Among the other $\mathrm{BN}$ that belong to the same semantic field different terms can be found: $L a$ Faribole, la Folie Grecque, l'Objectif, Au Bon vieux Temps, Le Nouveau Matin, Au Bon Coeur, Racines Bruxelles.

One more semantic field "Vehicles" can be distinguished among BN, that reflect tangible objects $(4 \%$ or 46 BN) : L'express, La brouette, La Rallye des Autos, Le Char d'Or, Le Tram Experience. Other BN can't be combined into semantic fields, as they refer to disparate notions, but in a number of cases the general trend is seen, as it was the case with other transpositional BN, to include evaluative elements: L'Eperon d'or, Pistolet Original, La Belle Equipe, La Clef d'Or, La Chaloupe d'Or, or to add localising items: Parfum d'Asie, L'estrille de Vieux Bruxelles, Feu du Bengale. We should also mention a number of BN from this group that came under our notice by their originality: Tour du Monde, Autre Chose, En Face de Parachute, La voix Secrète, Le Livre Jaune, Le Rubis, Etiquette, L'Arrière Pays, Le Cercle, L'Eau Chaude.

As we can see, established terms ( $3 \%$ or $35 \mathrm{BN})$ can also serve as unusual motivators of $\mathrm{BN}$, because very often they can have ambiguous sense. If we consider BN Rale-Bol, we will see that it can be interpreted as an idiom ("dissatisfaction"), but on the other hand, if we connect the separate meanings of words, it can be understood as "a full cup", which has a direct relationship to food. We deal with a similar situation, when we consider Mi-Figue Mi-Raisin, Le Coq en Pate and l'Eau a la Bouche. The case of Au Cor de Chasse is not less sophisticated, as it can be interpreted as an expression, that means "hunting horn". At the same time, it includes a hint at Chasse area, where the restaurant is situated and maybe also at paronymic word "coeur", and can be interpreted, as "at the heart of Chasse area". Other idioms have poetic function and attract addressees by this: Cote à Cote, Volle gas, La Bonne Franquette, Au Jour le Jour.

One of the most frequently used in $\mathrm{BN}$ phenomena is word-play $(5 \%$ or $58 \mathrm{BN})$, that increases the intensifying capacity of $\mathrm{BN}$ and its potential impact on the addressee. In our case we can distinguish such kinds of word-play, as 1) use of different abbreviations : Aub-Svp (abridged forms of "please" in Dutch and French), $C$ Bon (instead of C'est Bon), APDM (aux pays des merveilles as it is explained on the site of the restaurant),WY Brussels (welcome you); 2) use of figures and other semiotic systems : Sp@ce café, +39, Le 7 Ici, Le 6.6.6., The 65, Ninety One, Jet 7, SoHo 31, The One 52, 2 due, Peck 47, 1030 café, Restaurant $\mathrm{CO}$; 3) replacement of one of the words or elements of an established term by another: Nourritures Terrestres (nourriture celeste), Bistropolitan (Metropolitan), Brew Dog (Hot Dog), Arti Sauce (artichaut), La Barcamoule (la barque a voile), La Damoiselle (an unusual interpretation of la demoiselle), Wok Up (wake up replaced by Chinese wok); 4) unusual translation of a word, based on paronymy and homonymy, that leads to its re-interpretation: $A u$ Cent D'Wiches (les sandwiches), l'Auberg'In (l'aubergine), Bar B $Q$ (la barbecue), eccerera (etcaetera), Exki (Exquis), L'R du Temps (l'air du temps), L'Escal-Pates (l'escapade), Mon Pot Agé (le potage), Pick Quick Bis (from Pickwick Papers by Charles Dickens), Brinz/L (from brinzelle and Laure - the owner of the restaurant), Bon Bon (it can have double sense of a sweet or of the adjective bon), Le Chat Rabiat (charabia), D'Ici et D'ailleurs (ici et ailleurs "here and there" or d'ailleurs "anyway"), Fou d'Food (based on the combination of French and English units), Casa Nostra ( from the well-known cosa nostra); 5) juxtaposition of words, based on paronymy: Pasta e Basta, Bocca Moka, La Buca di Bacco.

There is also a phenomenon in motivational field of Brussels' restaurants, that shouldn't go without mention - this is the use of whole sentences (sentence based BN), that constitute $6 \%(69 \mathrm{BN})$ :

1) affirmative two-member sentences: Le Monde est Petit, Les Amis Dinent, C'est comme ça chez Panos, C'est pas raisonnable, in a number of cases they are evaluative and include positive attitude of the 
addressor: La Vie est Belle, C'est Bon, C'est Belge (the positive assessment is underlined here by the use of adjective bon, referring to food, but also Belge that points out national identity of the business);

2) imperative sentences that bond addressor and addressee owing to the effect of direct persuasion: Dinons ensemble, Be my stoemp (unusual combination of English and Flemish), 3) minor sentences: Bonsoir, Clara, Ah non, peut-être, Tout simplement, considering prospective customers, as interlocutors. We can also emphasise an interrogative two-member sentence, which is singular by its semantics and influences addressor by its peculiarity: Et Qui Va Ramener le Chien?

As it is known, state languages of Belgium are Flemish, French and German, therefore we believe it is necessary to distinguish $\mathrm{BN}$ in which national Belgian lexical units are used and those ones that are based on international lexical units $(21 \%$ or $242 \mathrm{BN})$. It must be noted that the majority of "national" $\mathrm{BN}$ are in French, and only a small part (3\%) - in Flemish: de Hoef, Bij den Boer, Moederlambic, In't Spinnekopke, De Monk, Talurelekker, Poechenelkelder, T'Kelderke. In our view, it can be explained to a greater extent by the popularity of French cuisine than by nationality or preferences of restaurant-keepers. All the other international BN constitute 18\% (207 BN). Making a distinction between "foreign" and "national" BN we will assume that foreign or international elements don't often have transparent semantics for addressees, sometimes only national distinctness can be identified, or BN remains totally incomprehensible to the nationals of the country. Conversely, we proceed from the assumption that there exists a motive in any kind of naming unit, although, it can be covert under some circumstances. Indeed, under condition that an ordinary citizen doesn't know any foreign language except Flemish and French, he or she will not guess the meaning of the following BN right: O-Bifanas (a pork burger in Portugese), Bia Mara (seafood in Irish), Kokob (a star in Corean), El Bocadillo (a sandwich in Spanish), Kafenio (a cafe in Greek), Chutney's (Indian meat rub), Hoplageiss ("Look out: a goat" in Alsacian dialect). In our research, we tried to emphasise languages that "participated" in the formation of Brussels restaurants' BN the most often. As we see, Italian ranks the first in this list, as it is the basis of 61 'international' BN: Gabbiani Reali, №7 Ristorante Italiano, Publico, Spago, Ciao Bella, Dolce Amaro, Il Perfetto, Roma Bella, Certo, La Mamma, Ai 6 Angoli, Il Passatempo, Delizie della Mamma, Mappa Mondo, I Latini, I Primi Piatti, Dolce Tentazione, Il Sorriso, Nonno, Senzanome. Such BN have a high degree of persuasion, because of the extreme popularity of healthy and tasty Italian food. English BN rank the second, as this is an international language and it performs an attractive function to the greatest extent. What is more, it is clear that a large part of addresses, coming to Brussels from across the world understand the direct meaning of BN written in English. They are: The Food Box, Greenway, Sea Grill, Moon Food, Cowfish, Wine in the city, The Twelve, Just Food, Knees to Chin, Old Wild West, The Black Sheep, Wild Geese, The Purple Rose, Bowery, Coming Soon, M'Eating Room, Food Maker, Green Kitchen, The Hairy Canary, Holy Bagels, Twins, The Music Village, God Save the Cream, The Place to be, So tasty, Mom 'seat \& Drinks, Crazy Salad (59 BN). We also would like to highlight the presence of a great number of BN in Japanese (33 BN): Makisu, Kamo, Yaki, Menma, La Tana, Kokuban, Samourai, Nonbe Daigaku, Inada, Hoshi Hoshi, Sakagura, Sakura, Umamido; in Chinese, Thai, Corean, Vietnamese, Indian (21 BN): Yi Chan, Tai Hon, Shao Shan, Sanh Kee, Tom Yam, Baan Chann, Hana, Mumtaz, Hong Hoa, Da-Kao. Such BN have a powerful attractive function at the expense of their special phonic form that indicates the presence of South and Eastern Asian roots. Consequently, there is no necessity to understand the meaning of words in the case, when their form is symbolic. This is true for all the cases mentioned in this section, and also for those ones, which are small in number (33 BN): Strofilia, Kafenio, Omiros, Snack Hellas, Mezze Polis (Having Greek origin), Un Posto al Sole, Comocomo, El Fontan, Le Brasero, Tapas Locas, La Cueva de Castilla (having Spanish origin), Al Jannah, Al Matbakh, Dar Dallia, Mazaj, Bab Dar, Al Barmaki (having Arabic origin), Caramulo, La Cantina, Pampas Rodizio (Having Portugese origin).

\section{Discussion and Conclusions}

The analysis of motivational characteristics of business names of restaurants in Brussels has shown that they are heterogeneous and range from the cases, which explicitly specify the profile of activity, the name of the owner and the address of a company, through $\mathrm{BN}$ where implicit information is added to the ones with vague and obfuscatory motive. As BN should act as persuaders imposing affective evaluation of the business and attracting attention of prospective consumer, transparency or vagueness of motivational characteristics do not immediately mean a low or high level of persuasion.

Trying to predict what the reaction of prospective customers to different categories of $\mathrm{BN}$ will be, we asked 146 Economics students from Taras Schevchenko National University of Kyiv, Ukraine that have Upper-Intermediate level of French and English to fill in a questionnaire, where $80 \mathrm{BN}$ from 8 different categories (10 $\mathrm{BN}$ from each one) were presented in random order. Having background knowledge of 
marketing techniques, they had to choose any $8 \mathrm{BN}$ from the whole list and rank them in order of degree of persuasion. Our survey showed that 92 students chose two or more BN from the same categories: in the majority of cases, these were transpositional and anthroponymic BN. These ones were followed by idiomatic and play on words categories. 25 students chose a few international $\mathrm{BN}$ and ranked them high. As a whole, 105 students didn't even choose sentence based, toponymic and background BN. As for the remaining 41 students, they underlined $8 \mathrm{BN}$ from 8 different categories. Consequently, we obtained the following ranking:

1. Anthroponymic BN.

2. Transpositional BN.

3. Play on words BN.

4. Idiomatic BN.

5. International $\mathrm{BN}$.

6. Sentence based BN.

7. Toponymic BN.

8. Background BN.

Using these data as a base let us consider the potential effect of BN from our classification:

- anthroponymic BN are able to influence addressees to the fullest extent, especially in the cases, when they represent a combination of "chez + name" or "a noun denoting close relationships + name". This happens at the expense of "feel at home" effect;

- toponymic BN don't have a lot of potential when it comes to persuasion. It is especially true for BN, where areas or streets of Brussels are mentioned. As for those ones, that use foreign geographic names, they can accomplish attractive function better, but only in the case if addressees have enough background knowledge to understand what they can be associated with (Hello Saigon includes a hint at Vietnamese cuisine, as Saigon is situated in Vietnam);

- the same is also true for background BN that are tailored to tastes of well-educated public but do not have any persuading ability in case of ordinary people. Background BN speak even more about the level and preferences of addressors than about their persuading force;

- transpositional BN, especially those ones that are connected with the semantic field "Food and drinks", are effective in attracting prospective customers, as, on the one hand, they often give direct information about the food that can be found at the restaurants (Les Crustacés), and, on the other hand, add unusual associations to ordinary things (Comptoir des Saveurs, La Boussole Brassière). The use of semantic field "People" also has a high potential of persuasion, it often creates the effect of familiarity. This is particularly true when the seme "Family and other close relationships" is forefolded. As a whole, this kind of $\mathrm{BN}$ can be considered as the most advantageous for nomination and having the highest level of persuasion;

- idiomatic BN are closely connected with transpositional ones and are as effective as the latter;

- we believe that play on words is also a very efficient tool in attracting customers, as it is able to catch their interest even only by the form of BN and sometimes also by its content;

- sentence based BN are able to arouse addressees' interest owing to the effect of dialogue that they create, and also some additional shades of meaning, consequently, they have a good potential, when it comes to persuasion;

- the effect of international BN is controversial: in cases, when people know the language of $\mathrm{BN}$, it can be placed into one of the categories above, according to the meanings of words, word combinations and sentences that they represent; otherwise the sound form of BN can suggest to what national cuisine the restaurant belongs. Consequently, in general case, international BN can be attractive only as a reminder of "nationality" of food.

At last, we would like to answer the question that is of a great importance for those people, who want business names of their companies to influence and persuade prospective customers and try products and services that they provide. The question is: "What are the main features of a successful BN if we speak about the names of restaurants?" Finally, we believe that recommendations we developed will provide the needed linguistic manipulation and think that BN should:

- highlight the profile of the activity of a business;

- contain anthroponymic elements;

- be personalised, custom-made, unusual (semantic transpositions are welcome in this case);

- be simple, aimed at average customer audience,

- be exceptional by its form. 
Finally, we would like to outline the prospects for further research in the field and emphasise the necessity to study and compare the data from the languages that belong to different language systems, i.e. English, French, and Ukrainian. In this way, it will be possible to establish a typology of business names in these languages and identify a number of characteristics relevant for the naming process.

\section{References:}

Argenti, P. \& Forman J. (2002). The power of corporate communication. Crafting the voice and image of your business. New-York: McGraw-Hill.

Bergien, A. (2005). Global and regional considerations in the formation of company names. In Maria G. Arcamone, Davide De Camilli \& Bruno Porcelli (Eds), Proceedings of the $22^{\text {nd }}$ International Congress of Onomastic Sciences (pp. 289-298). Pisa: Onomastica e Societa.

Hauser, M. D. \& Fitch, W. T. (2003). What are the uniquely human components of the language faculty? In M.H. Christiansen \& S. Kirby (Eds), Language evolution (pp. 158-181). Oxford: Oxford University Press.

Pinker, S. \& Bloom, P. (1990). Natural language and natural selection. Behavioral and Brain Sciences, 13, 707-784.

Riley, P. (2007). Language, culture and identity. An ethnolinguistic perspective. London: Continuum.

Sériot, P. (2013). La langue pense-t-elle pour nous? La Linguistique, 1 (49), 115-131. https://doi.org/10.3917/ling.491.0115

Sjoblom, P. (2007). Finnish company names; structure and function. In Ludger Kremer, Elke Ronneberger-Sibold (Eds), Names in commerce and industry: past and present (pp. 289-295). Berlin: Logos.

Sweetser E. (2017). Metaphor and metonymy in advertising: building viewpoint in multimodal multi-space blends. Journal of pragmatics, $122,65-76$.

Tomasello, M. (2003). Constructing a language: A usage-based theory of language acquisition. Cambridge MA: Harvard University Press.

Received: March 06, 2018

Accepted: December 06, 2018 